\title{
ТОРГОВО-ЭКОНОМИЧЕСКИЕ ОТНОШЕНИЯ РОССИЙСКОЙ ФЕДЕРАЦИИ И ЕВРОСОЮЗА
}

\section{(c) 2021 Исраилова Элима Адамовна}

доктор экономических наук, доцент, и.о. зав. кафедрой «Мировая политика и глобализация» Ростовский государственный экономический университет (РИНХ), Россия, Ростов-на-Дону

E-mail: elima84@mail.ru

В статье проанализированы основные аспекты торгово-экономических отношений России и Европейского союза. Выделены последствия выхода Великобритании из Европейского Союза для стабильности как ЕС, так и еврозоны. В данной работе проведен анализ торгово-экономических отношений между государствами-членами ЕС и Россией под влиянием санкций в отношении отдельных российских компаний и граждан, а также ответных мер РФ в отношении импорта отдельных видов продукции из европейских стран.

Ключевые слова: торгово-экономические отношения, международные экономические отношения, Российская Федерация, Европейский союз.

В современном мире ни одно государство или интеграционный союз не могут развиваться и существовать обособленно, что обусловлено экономическими, политическими, научнотехническими, общественными и рядом других объективных факторов. Россия и Европейский союз (ЕС) в силу территориального, исторического и геополитического факторов являются внешнеэкономическими партнерами с длительной историей взаимоотношений, которые под воздействием ряда причин и событий постоянно претерпевают изменения.

В первые годы существования Европейского экономического сообщества (ЕЭС) основной целью бюджета (который в то время был основан на трансфертах из государств-членов) было финансирование общей сельскохозяйственной политики.

Реформа 1971 года создала концепцию собственных ресурсов, которая состоит из таможенных пошлин, применяемых к товарам, импортируемым из-за пределов Сообщества, и сельскохозяйственных пошлин, взимаемых с импорта в ЕЭС, направляемых в европейский бюджет. С 1970 года расходы по сельскохозяйственной политике увеличивались, за счет появления новых областей деятельности, представляющих интерес для поддержки регионального развития и, следовательно, это потребовало дополнительных платежей государств-членов.

В 1979 году был введен третий источник финансирования, состоящий из небольшого процента сумм, собранных через налог на добавлен- ную стоимость каждым государством-членом. Хотя расходы на общую сельскохозяйственную политику невозможно контролировать и традиционные собственные ресурсы продолжали сокращаться, НДС вскоре оказался недостаточным.

Соответственно, в июне 1988 года Европейский совет в Брюсселе ввел новый собственный ресурс, рассчитанный из собственного валового национального дохода (ВНД) каждого государства-члена [5].

Бюджет Евросоюза является постоянным предметом острой политической борьбы отдельных государств-членов ЕС. Вопрос, связанный с суммой выплат в казну Союза отдельными государствами ЕС, порождает особые противоречия. Ни одно государство не согласится быть чистым плательщиком объединения в течение длительного периода времени. Более того, можно заметить снижение уровня энтузиазма, связанного с приемом новых стран в ЕС. Это связано с тем, что расширение Союза новыми государствамичленами влечет за собой необходимость расходования большого количества активов из бюджета ЕС на финансовую поддержку и развитие экономики новых стран-членов, чей государственный и технологический уровень далек от среднего уровня по Союзу. Эта ситуация заставляет предмет общего бюджета Европейского Союза становиться все более обсуждаемой категорией государственных финансов Союза [6].

Распределение «доноров» и «реципиентов» субсидий оставалось относительно стабильным на протяжении многих лет и подлежит доволь- 
но легкому разделению по региональным и хронологическим критериям. Среди наиболее развитых стран выделяются в основном страныоснователи Европейского Союза - это экономики Северной и Западной Европы, которые и являются основными «донорами». Большинство субсидий получают страны Южной, Центральной и Восточной Европы, в то время как все страны Центральной и Восточной Европы входят в число новых членов ЕС.

Добавление «новых» государств в 2004, 2007 годах, в которых уровень развития был ниже, чем у «старых» членов, несомненно, повлиял на европейскую интеграцию, тем более что ни один из этих новых членов не стал чистым вкладчиком.

За весь рассматриваемый период до и после расширения ЕС до 28 стран в конечном итоге можно выделить “вечно проигрывающие” шесть стран (Германия, Франция, Великобритания, Италия, Нидерланды и Швеция), которые являются основными плательщиками и “вечно выигрывающие” семь стран (Польша, Испания, Греция, Португалия, Венгрия, Румыния и Чехия), которые получают больше дотаций, чем остальные государства объединения.

Два кризиса, потрясшие зону евро, а также впоследствии сложная ситуация, сложившаяся в Греции и ряде экономик в южных странах ЕC, привели к обострившимся взаимным обвинениям. «Страны-доноры» обвинили «новые» страны, которые являются «реципиентами» объединения в том, что они существуют за счет дотаций, выделяемых странами с более развитыми экономиками. Кроме того, осложнял данную ситуацию также поток дешевой рабочей силы, хлынувший из стран Восточной Европы [1].

Можно отметить, что еще даже до расширения Европейского Союза во время двух кризисов и уже после, состав стран - доноров не изменился. Получается, что основную долю общих взносов за весь рассматриваемы период (2000-2018 годы) внесли: Германия (400,08\%), Франция $(271,37 \%)$, Италия $(259,29 \%)$ и Великобритания (211,44\%).

Учитывая, что Brexit породил огромное количество неопределенности относительно будущего экономической политики, такая неопределенность может влиять на поведение с долгосрочными последствиями, то есть в инвестиционных решениях, что ведет к снижению инвестиций в крупнейшие экономики еврозоны, а также влияет на текущую и будущую денежнокредитную политику.

Подрывает ли Brexit Европейский союз как политический и экономический проект? И как повлияет выход Великобритании на стабильность в зоне евро? Выход Великобритании из Европейского Союза будет иметь несколько последствий для стабильности как ЕС, так и еврозоны.

Brexit может повлиять на государственные финансы EC, так как это процесс несомненно укрепит существующие разногласия между «донорами» и «реципиентами» бюджета ЕС. Без Великобритании бюджет Евросоюза столкнется с постоянным дефицитом финансирования. В связи с выходом Великобритании возникла необходимость формирования и согласования нового долгосрочного бюджета на 2021-2027 годы [2].

Неопределенность, сопровождающая Brexit, вероятно, окажет умеренное негативное влияние на стабильность в еврозоне, поскольку Великобритания никогда не была и не собиралась быть частью евро, поэтому устранение государства-члена, которое не было частью евро означает, по сути не затрагивает еврозону.

Но масштабы Brexit означают, что это процесс предлагает ЕС некоторую гибкость в его институциональном строительстве в рамках различных проектов зоны евро (объединение банков / рынков капитала, гармонизация бюджета или другие макроэкономические показатели). То есть, чтобы защитить крупномасштабную налогово-бюджетную политику или разработать новую формальную архитектуру банковского союза, в центре внимания ЕС должно быть создание институтов, которые будут способствовать необходимой конвергенции стран, состоящих и вступающих в зону евро, а также возможность разработки нового договора между странами о распределении бремени, чтобы нести расходы на сближение. Такой контракт будет учитывать временной аспект, необходимый для сближения стран, отсутствующий в первоначальной архитектуре [4].

Таким образом, напряженность между более богатыми государствами- членами и более бедными государствами-получателями всегда характеризовала историю бюджета Европейского союза. Статистика показывает, «старые» наиболее развитые страны ЕС должны были обеспечивать не только страны юга, имеющие проблемы, 
но и «новые» государства ЕС, принятые в 2004 и 2007 годах, которые успешно развивались лишь благодаря массивным финансовым вливаниям Евросоюза. При этом остается не решенным вопрос по новому бюджетному плану. Крупнейшие плательщики Союза либо пострадают от увеличения взносов, в то время как получатели будут относительно не затронуты, либо сокращение общего бюджета нанесет ущерб получателям.

Отсюда следует, что начавшийся в 2007-2008 годах кризис выявил не только сугубо финансовые проблемы неэффективного управления государственным долгом и низкой бюджетной дисциплины, но также и проблемы, лежащие в плоскости геополитики и геоэкономики.

Так, именно «политические ошибки» препятствовали сближению стран и стабильности зоны евро, то есть еще до ввода евро и в докризисные годы основные принципы пребывания в составе ЭВС неоднократно нарушались различными странами. А также в последствии расширения ЕС стал охватывать страны с различными структурами и различными конкурентными возможностями, поэтому более бедные страны должны были «догонять» более богатые страны. В итоге, долговой кризис Европейского союза является также результатом не только мирового финансового кризиса, но и результатом неспособности некоторых стран обеспечить контроль над растущим долгом, что создало огромное давление на стабильность и выживание единой европейской валюты.

Европейский кризис суверенного долга был переплетен с финансовым кризисом и оказал серьезное давление на финансовый сектор и вздутый государственный бюджет зоны евро. Проблемы усугублялись макроэкономическими дисбалансами, возникшими в нескольких государствах- членах. Кроме того, замедление экономической активности привело к сокращению налоговых поступлений, что привело к тому, что высокий дефицит бюджета стал неприемлемым. Поэтому сильное расхождение стран по экономическому развитию привело к формированию экономической политики всего Евросоюза, в основном, в интересах лидирующих стран в ущерб национальным интересам других стран-участниц. Экономическая разнородность стран привела к конфликту интересов касательно ассигнований между странами-участницами. Исходя из этого, включение стран Восточной Европы спровоцировало очередной виток кризиса в странах Южной Европы (Греции, Италии, Испании и Португалии), которые были до того момента основными бенефициарами помощи со стороны более развитых стран ЕС.

Восстановление российской внешней торговли с Европейским союзом после глобального финансово-экономического кризиса 2009 г. прошло достаточно быстро. После 2014 г. развитие торгово-экономических отношений между государствами-членами ЕС и Россией находилось под воздействием введенных западными странами санкций в отношении отдельных российских компаний и граждан, а также ответных мер России в отношении ввоза отдельных видов продукции из европейских стран. Этот негативный политический фон сказался на объемах двусторонней торговли между Россией и отдельными европейскими странами.

В целом с 2001 г. по 2020 г. удельный вес ЕС в российском импорте сократился с 41,7\% до $34,1 \%$, а доля этой группы стран в экспорте России - с 50,1\% до 33,9\%. Влияние пандемии также отразилось на торговле России с ЕС. За 2020 г. экспорт в эту группу стран уменьшился на 63 млрд. долл., а импорт сократился на 6 млрд. долл.

Таким образом, до тех пор, пока противоречия не будут преодолены, взаимодействия между РФ и ЕС останутся в большей степени отношениями соперничества. Соответственно, ближайшая общая задача России и Европейского союза состоит в сокращении издержек и снижении рисков, неразрывно связанных с существующим соперничеством.

\section{Библиографический список}

1. Приемская Е. Как живут страны-«иждивенцы» и страны-«доноры» в ЕС / Приемская Е., Халитова А // «Известия», 2017 [Электронный ресурс] - Режим доступа: https://iz.ru/news/665771

2. European Commission / EU budget 2021-2027: Time to decide, Press release, 2019 [Электронный ресурс] — Pежим доступа: https://ec.europa.eu/commission/presscorner/detail/en/IP_19_6039

3. European Commission /EU expenditure and revenue 2014-2020 [Электронный ресурс] - Режим доступа: https://ec.europa.eu/budget/graphs/revenue_expediture.html 
4. Hartwell C. An assessment of the impact of Brexit on euro area stability /Hartwell C., Horvath R. // Monetary Dialogue, European Parliament, 2016.- P.33-54

5. Ionescu G. The consequences of global financial crisis over European Union budget. /Ionescu G. //Romanian Economic Business Review. No4, 2009.- P. 28-39. [Электронный ресурс] - Режим доступа: http://www.rebe. rau.ro/RePEc/rau/journl/SP09/REBE-SP09-A4.pdf

6. Niedzielski B. General Budget of the European Union. /Niedzielski В.// Ekonomia journal. No18, 2007 [Электронный ресурс] - Режим доступа: https://www.researchgate.net/publication/46553399_General_Budget_of_the_ European_Union

7. Rubio E. Brexit and the EU budget: threat or opportunity? /Rubio E., Haas J.// Bertelsmann Stiftung. 2017.- P.118 [Электронный ресурс] - Режим доступа: https://www.researchgate.net/publication/312939055_Brexit_and_ the_EU_budget_threat_or_opportunity 